\title{
Cell-specific Posttranslational Events Affect Functional Expression at the Plasma Membrane but not Tetrodotoxin Sensitivity of the Rat Brain IIA Sodium Channel $\alpha$-Subunit Expressed in Mammalian Cells
}

\author{
Xian-cheng Yang,, ${ }^{1}$ Cesar Labarca, ${ }^{1}$ Joel Nargeot, ${ }^{2}$ Begonia Y. Ho, ${ }^{1}$ Orna Elroy-Stein,, ${ }^{3}$ Bernard Moss, ${ }^{3}$ Norman \\ Davidson, ${ }^{1}$ and Henry A. Lester ${ }^{1}$ \\ 'Division of Biology, California Institute of Technology, Pasadena, California 91125, ${ }^{2}$ Centre de Biochimie \\ Macromoleculaire, CNRS, 34033 Montpellier, France, and 'aaboratory of Viral Diseases, NIAID, NIH, Bethesda, \\ Maryland 20892
}

The rat brain IIA $\mathrm{Na}^{+}$channel $\alpha$-subunit was expressed and studied in mammalian cells. Cells were infected with a recombinant vaccinia virus (VV) carrying the bacteriophage T7 RNA polymerase gene and were transfected with CDNA encoding the IIA $\mathrm{Na}^{+}$channel $\alpha$-subunit under control of a T7 promoter. Whole-cell patch-clamp recording showed that functional IIA channels were expressed efficiently ( $\sim 10$ channels $/ \mu \mathrm{m}^{2}$ in $\sim 60 \%$ of cells) in Chinese hamster ovary (CHO) cells and in neonatal rat ventricular myocytes but were expressed poorly in undifferentiated $\mathrm{BC}_{3} \mathrm{H} 1$ cells and failed to express in Ltk ${ }^{-}$cells. However, voltage-dependent Drosophila Shaker $\mathrm{H}_{4} \mathrm{~K}^{+}$channels and Escherichia coli $\beta$-galactosidase were expressed efficiently in all four cell types with VV vectors. Because RNA synthesis probably occurs without major differences in the cytoplasm of all infected cell types under the control of the T7 promoter and T7 polymerase, we conclude that cell type-specific expression of the $\mathrm{Na}^{+}$channel probably reflects differences at posttranslational steps. The gating properties of the IIA Na+ currents expressed in cardiac myocytes differed from those expressed in CHO cells; most noticeably, the IIA $\mathrm{Na}^{+}$currents displayed more rapid macroscopic inactivation when expressed in cardiac myocytes. These differences also suggest cell-specific posttranslational modifications. IIA channels were blocked by $\sim 90 \%$ by $90 \mathrm{nM}$ TTX when expressed either in $\mathrm{CHO}$ cells or in cardiac myocytes; the latter also continued to display endogenous TTX-resistant $\mathrm{Na}^{+}$currents. Therefore, the TTX binding site of the channel is not affected by cell-specific modifications and is encoded by the primary amino acid sequence.

Expression of voltage-gated $\mathrm{Na}^{+}$channels is cell specific (Grubman et al., 1988; Maue et al., 1990). cDNAs encoding different isoforms of the $\alpha$-subunit of the $\mathrm{Na}^{+}$channel have been identified from mammalian tissues: four from the brain [types I, -II, -IIA (different from II by six amino acids), and -III; Noda

\footnotetext{
Received May 6, 1991; revised Aug. 15, 1991; accepted Aug. 26, 1991.

We thank Carolyn Nolan and Euk Kwon for excellent technical assistance. This work is supported by grants from the NIH (NS-11756 and GM-29836), the Muscular Dystrophy Association, the Multiple Sclerosis Society, and NATO (CRG 890374) and by postdoctoral fellowships from the Muscular Dystrophy Association (X.-C.Y.) and the American Heart Association, Greater Los Angeles Chapter (B.Y.H.).

Correspondence should be addressed to Henry A. Lester, Division of Biology 156-29, California Institute of Technology, Pasadena, CA 91125.

Copyright (C) 1992 Society for Neuroscience $0270-6474 / 92 / 120268-10 \$ 05.00 / 0$
}

et al., 1986a; Auld et al., 1988], two from skeletal muscle (SkM1 and SkM2; Trimmer et al., 1989; Kallen et al., 1990), and two from the heart (RH-I and CSCI; Rogart et al., 1989; Sills et al., 1989). Maue et al. (1990) provide evidence that cell-specific expression of the $\alpha$-subunit of brain II $\mathrm{Na}^{+}$channel is controlled at the transcription level by regulatory sequences upstream from the channel promoter. It is not known whether the cell-specific expression of $\mathrm{Na}^{+}$channels can also be controlled at translational or posttranslational steps.

One of the pharmacological characteristics of voltage-gated $\mathrm{Na}^{+}$channels is their sensitivity to TTX. Like native neuronal $\mathrm{Na}^{+}$channels (Hille, 1984; Ulbricht et al., 1986; Huguenard et al., 1988), rat brain type II (or -IIA) $\mathrm{Na}^{+}$channels when expressed in Xenopus oocytes (Noda et al., 1986b, 1989) and in CHO cells (Scheuer et al., 1990) are sensitive to TTX with an apparent dissociation constant, $K_{d}$, of $\sim 10 \mathrm{nM}$. In contrast, native cardiac $\mathrm{Na}^{+}$channels are resistant to TTX with a $K_{d}$ of $\sim 1$ $\mu \mathrm{M}$ (Catterall and Coppersmith, 1981; Cohen et al., 1981). A point mutation, replacing a glutamic acid residue by a glutamine at position 387 in the type II amino acid sequence, renders the channel resistant to TTX (Noda et al., 1989). The rat heart I (RH-I) and the skeletal muscle II (SkM2, identical to RH-I) $\mathrm{Na}^{+}$ channels have a natural glutamine at the position corresponding to position 387 in the brain II $\mathrm{Na}^{+}$channel (Rogart et al., 1989; Kallen et al., 1990). When expressed in oocytes, the RH-I and SkM2 mRNA and heart RNA encode $\mathrm{Na}^{+}$channels that are resistant to TTX (Cribbs et al., 1990; Krafte et al., 1991; White et al., 1991), contrary to our earlier experiments with heart RNA (Sutton et al., 1988). These observations taken together support the hypothesis that TTX sensitivity of $\mathrm{Na}^{+}$channels is determined by the primary amino acid sequences. However, they do not rulc out the possibility that TTX-binding sites of $\mathrm{Na}^{+}$channels may also be subject to different posttranslational modifications in neurons versus cardiac myocytes.

Voltage-gated $\mathrm{Na}^{+}$currents in oocytes injected with high molecular weight brain RNA or IIA RNA have a much slower inactivation time course than do (1) the currents in oocytes injected with total rat brain RNA (Auld et al., 1988; Krafte et al., 1988, 1990) or (2) $\mathrm{Na}^{\prime}$ currents observed in central neurons (Huguenard et al., 1988). This slower $\mathrm{Na}^{+}$channel inactivation rate is corrected by coinjection of low molecular weight brain RNA along with high molecular weight or IIA RNA into oocytes. It is plausible that the low molecular weight brain RNA encodes the $\beta$-subunits of the $\alpha \beta_{1} \beta_{2}$ complex of brain $\mathrm{Na}^{+}$channels (Messner and Catterall, 1985) and that association of $\alpha$ with 
one or both $\beta$ s affects the inactivation rate. Alternatively, the low molecular weight RNA may encode an enzyme that participates in posttranslational covalent modifications of the $\alpha$ subunit. However, when expressed in mammalian cells, the $\alpha$ subunits of brain IIA and the muscle type I (SkM1 or $\mu \mathrm{I}) \mathrm{Na}^{+}$ channels have a much faster inactivation time course (Scheuer et al., 1990, 1991; Ukomadu et al., 1991). The rat brain III Na ${ }^{+}$ channels expressed in oocytes following RNA injection have alternating slow- and fast-gating modes when observed by single-channel recording, corresponding to a 10 -fold difference in inactivation time constants of the macroscopic currents (Moorman et al., 1990). Deletion mutations (Stuhmer et al., 1989) and sequence-directed antibodies (Vassilev et al., 1988) provide evidence that the internal loop between membrane repeats III and IV of brain and skeletal muscle $\mathrm{Na}^{+}$channels is involved in channel inactivation. All told, one can only conclude from the several observations summarized above that the molecular mechanisms for $\mathrm{Na}^{+}$channel inactivation are not fully understood.

In this article, we provide evidence for cell-specific posttranslational processing of the $\alpha$-subunit of the rat brain IIA $\mathrm{Na}^{+}$ channel expressed in mammalian cells. We wish to note at this point that for brevity we use the phrase "posttranslational processing" in its most general sense, including not only covalent modification such as glycosylation or phosphorylation, but also association with other subunits that may be necessary for assembly and function of the channel on the plasma membrane. We have found that the IIA channel $\alpha$-subunit is expressed at a high density on the plasma membrane in Chinese hamster ovary $(\mathrm{CHO})$ cells and in neonatal rat ventricular myocytes using a vaccinia virus (VV) vector system, but there is little or no functional expression in undifferentiated mouse $\mathrm{BC}_{3} \mathrm{H} 1$ cells or in mouse Ltk ${ }^{-}$cells. That this effect is not due to the peculiarities of the vector system is suggested by our observation that a voltage-gated $\mathrm{K}^{+}$channel can be expressed in all four cell types with the same $\left(\mathrm{CHO}, \mathrm{BC}_{3} \mathrm{H} 1\right.$, and $\mathrm{Ltk}^{-}$cells) or a similar (cardiac myocytes; Karschin et al., 1991) vector system. We have further found that the IIA channel was sensitive to TTX when expressed in either $\mathrm{CHO}$ cells or ventricular myocytes, although the latter have TTX-resistant, endogenous $\mathrm{Na}^{+}$channels. This result indicates that TTX sensitivity is encoded in the primary sequence. However, kinetic properties of the IIA $\mathrm{Na}^{+}$channel expressed in $\mathrm{CHO}$ cells differed somewhat from those in ventricular myocytes.

In this work, we have employed the infection-transfection version of the vaccinia virus-bacteriophage $\mathrm{T} 7$ hybrid expression system (VV/T7, Fig. 1A) for expression of ion channels for two reasons. (1) The wide host range of VV allows us to attempt expression of the channel in various mammalian cells including primary cells such as cardiac myocytes and thus to identify possible cell-specific expression of the channel. (2) Transcription of the channel cDNA is controlled by a bacteriophage T7 promoter and T7 RNA polymerase in the cytoplasm of infected cells. Therefore, cell-specific differences in expression and properties of the IIA $\mathrm{Na}^{+}$channel in different mammalian cells are independent of cellular differences in transcriptional controls and are expected to involve only translational or posttranslational steps.

\section{Materials and Methods}

Virus and plasmids. A recombinant vaccinia virus, vTF7-3, containing the bacteriophage T7 RNA polymerase gene, was used in the experi-
A
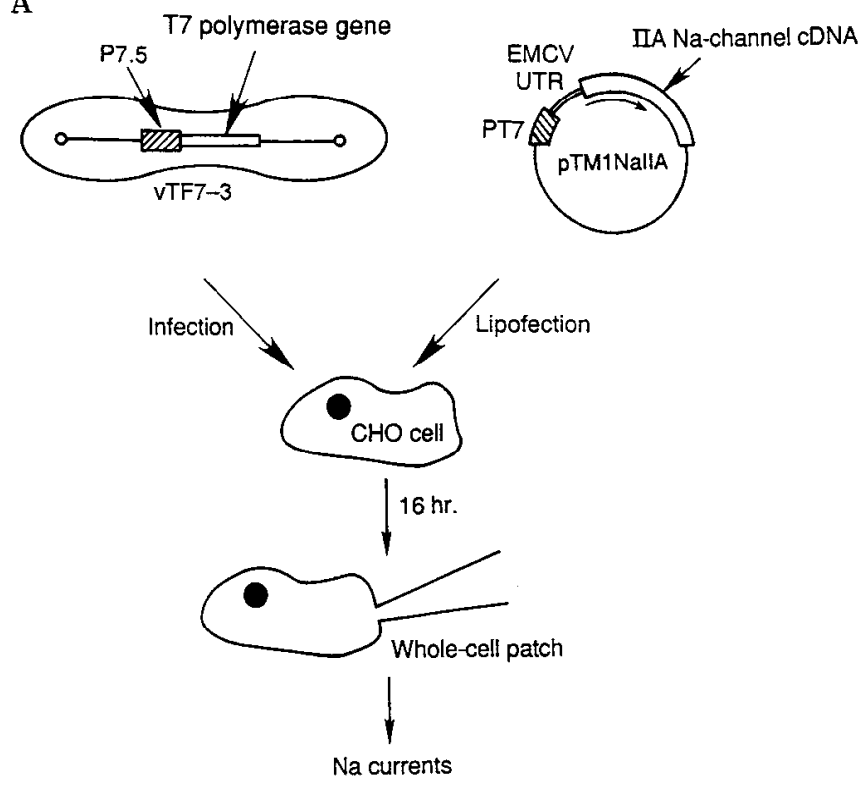

B

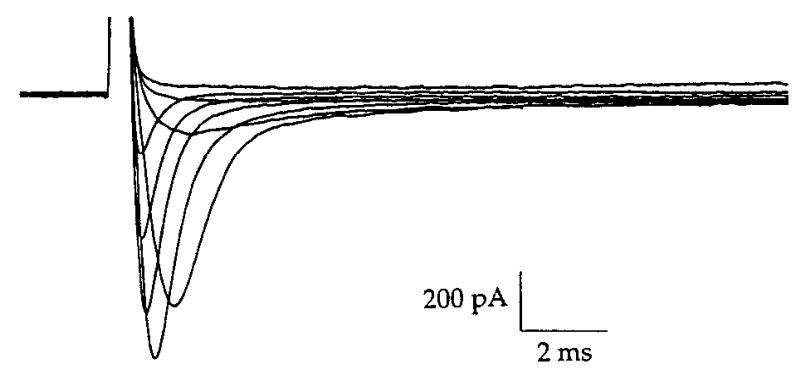

Figure 1. Expression of IIA $\mathrm{Na}^{+}$channels in CHO cells. $A$, The infection-transfection version of the VV/T7 system. The recombinant VV $v T F 7-3$ contains the bacteriophage $T 7$ RNA polymerase gene controlled by a VV early promoter, $P 7.5$. In the plasmid pTM 1 NaIIA, $P T 7$ is a T7 promoter; the EMCV UTR confers tight binding of the target gene to the ribosome and increases the translational efficiency. The T7 terminator downstream of the IIA cDNA is not shown. $B, \mathrm{Na}^{+}$currents recorded from a CHO cell infected with VTF7-3 and transfected with pTMINaIIA. External $\mathrm{Na}^{+}, 10 \mathrm{~mm}$; holding potential, $-100 \mathrm{mV}$; depolarizing test potentials were -70 to $+20 \mathrm{mV}$ at $10 \mathrm{mV}$ increments. The interval between test pulses was 4 sec.

ments (Fuerst et al., 1986; Elroy-Stein et al., 1989). Three plasmids used in our experiments were pTMl (Moss et al., 1990) carrying the $\alpha$-subunit of rat brain IIA Na+ channel cDNA (Yang et al., 1991), the Drosophila Shaker H4 K+ channel cDNA (H. S. Hsu, X.-C. Yang, A. Karschin, C. Labarca, A. Figl, N. Davidson, and H. A. Lester, 1991, unpublished observations) or the Escherichia coli $\beta$-galactosidase gene (Fuerst et al., 1986; Elroy-Stein et al., 1989), named pTM1NaIIA, pTM1KH4, and pTM1LacZ, respectively. The IIA $\mathrm{Na}^{+}$channel has a leucine rather than phenylalanine at codon 860 (Auld et al., 1990). In pTM1NaIIA, the $\mathrm{Na}^{+}$channel cDNA was placed immediately $3^{\prime}$ to the encephalomyocarditis virus (EMCV) untranslated region (UTR) in pTM1 by including the start codon of the $\mathrm{Na}^{+}$channel in an $\mathrm{Ncol}$ site (Yang et al., 1991).

Cells. Cells were maintained at $37^{\circ} \mathrm{C}$ in $5 \% \mathrm{CO}_{2}$. Mammalian cell lines used in our experiments were CHO-K1 [maintained in $\alpha$-minimum essential medium ( $\alpha \mathrm{MEM}$ ) plus $5 \%$ fetal bovine serum (FBS), mouse Ltk $^{-}$[MEM, $10 \%$ FBS, and TAGG (thymidine, $160 \mu \mathrm{M}$; adenosine, 50 $\mu \mathrm{M}$; guanosine, $50 \mu \mathrm{M}$; glycine, $50 \mu \mathrm{M}$ ], and mouse $\mathrm{BC}_{3} \mathrm{Hl}$ cells (Dulbecco's modified Eagle's medium, 20\% FBS).

Ventricular myocytes were prepared from newborn rat (2-3 d old) following a procedure similar to that described by Blondel et al. (1970). In brief, after dissection and separation from atria, the ventricles from six to eight rats were washed twice with PBS (Delbecco phosphate buffer 
solution free of $\mathrm{Ca}^{2+}$ and $\mathrm{Mg}^{2+}$; Irvine Scientific, Santa Ana, CA) and cut into $1 \mathrm{~mm}$ pieces. The tissue fragments were treated with trypsin $(1 \times$ EDTA trypsin, Irvine Scientific) for nine successive 5 min periods at $37^{\circ} \mathrm{C}$. The first three supernatants were discarded. Each subsequent supernatant was collected in a centrifuge tube containing an equal volume of growth medium and placed in ice water. Supernatants were pooled together and centrifuged at $1300 \mathrm{rpm}$ for $15-20 \mathrm{~min}$. The cell pellet was resuspended in $20 \mathrm{ml}$ of culture medium, then plated in 60 mm culture dishes (Corning Glass Works, Corning, NY) and incubated at $37^{\circ} \mathrm{C}$ for $1.5 \mathrm{hr}$, during which most fibroblasts rather than ventricular cells attached to the dish surface. The supernatant was collected and plated in $35 \mathrm{~mm}$ culture dishes (Corning). After incubation at $37^{\circ} \mathrm{C}$ for 16-24 $\mathrm{hr}$, the cultures were washed three times with PBS containing $\mathrm{Ca}^{2+}$ and $\mathrm{Mg}^{2+}$ and fed with fresh medium. The growth medium was minimum essential medium Earle's salts (Whittaker Bioproducts, Walkersville, MD) plus 10\% FBS (Irvine Scientific), 2\% MEM amino acids (Flow Laboratories, McLean, VA), 1\% nonessential amino acids (Flow), $2 \%$ MEM vitamins (Sigma), $2 \mathrm{~mm} \mathrm{L-glutamine} \mathrm{(GIBCO),} 100 \mathrm{U} / \mathrm{ml}$ penicillin, and $100 \mu \mathrm{g} / \mathrm{ml}$ streptomycin.

Infection and transfection. Sixteen to twenty-four hours before infection, cells were plated at densities (cells per $35 \mathrm{~mm}$ culture dish) of 2 $\times 10^{5}$ for $\mathrm{CHO}$ cells, $1-5 \times 10^{5}$ for Ltk cells, $5 \times 10^{4}$ for $\mathrm{BC}_{3} \mathrm{H} 1$ cells, and $\sim 10^{4}$ for ventricular myocytes. vTF7-3 stored at $-80^{\circ} \mathrm{C}$ was quickly thawed at $37^{\circ} \mathrm{C}$ and then diluted in PBS plus $1 \mathrm{mM} \mathrm{MgCl}_{2}$ and $0.1 \%$ bovine serum albumin. After growth medium was removed from the dish, cells were washed once with $1 \mathrm{~mm} \mathrm{MgCl}_{2}$ in PBS. The dish was rocked three to five times after addition of $0.3-0.4 \mathrm{ml}$ of viral inoculum and incubated at $37^{\circ} \mathrm{C}$ for $30 \mathrm{~min}$, during which the dish was rocked every $10 \mathrm{~min}$. At the end of incubation, viral inoculum was removed from the dish and $1 \mathrm{ml}$ of serum-free growth medium was added. We infected cells with vTF7-3 at multiplicities of $1,5,10$, or 30 plaqueforming units per cell. We found that the multiplicity of 10 gave the best expression of the IIA Na${ }^{+}$channel, the Shaker $\mathrm{H}_{4} \mathrm{~K}^{+}$channel, and $\beta$-galactosidase with gond viability of infected cells. The results reported in this article were obtained from cells infected with vTF7-3 at a multiplicity of 10 .

We followed a lipofectin-mediated DN $\Lambda$ transfection protocol (Bcthesda Research Laboratories Life Technologies, Inc., Gaithersburg, MD). In brief, plasmid DNA ( $4 \mu \mathrm{g}$ of pTM1NaIIA, pTM1KH4, or pTM1LacZ DNA per $35 \mathrm{~mm}$ dish) and lipofectin solutions (in water) were prepared separately in two polystyrene tubes with final volumes of 50 or $100 \mu 1$ in each tube, depending on the amount of DNA used. Following gentle tapping of the tubes, the lipofectin solution was added to the DNA solution. The ratio of lipofectin to DNA was 3 to 1 by weight in the mixture. The mixture was incubated at room temperature for $20 \mathrm{~min}$ and then added dropwise into the dish containing vTF7-3infected cells bathed in serum-free growth medium. After incubating at $37^{\circ} \mathrm{C}$ for $16-24 \mathrm{hr}$ following infection and transfection, the cells were fed with serum-containing growth medium.

Staining pTM1LacZ-transfected cells. Sixteen to twenty-four hours after cells were infected with vTF7-3 and transfected with pTM1LacZ, the serum-free growth medium was removed. The cells were washed once with PBS and fixed with 3.7\% formaldehyde (in PBS) at room temperature for $15 \mathrm{~min}$. The fixed cells were washed once with PBS and stained with 5 -bromo-4-chloro-3-indolyl- $\beta$-D-galactoside (Xgal; 1 $\mathrm{mg} / \mathrm{ml}$ in PBS containing $5 \mathrm{~mm}$ ferrocyanide and $5 \mathrm{~mm}$ ferricyanide, $\mathrm{pH} 7.3$; Sanes et al., 1986). Following $2-4 \mathrm{hr}$ incubation at $37^{\circ} \mathrm{C}$, the stained cells were observed under an inverted microscope.

Electrophysiology. The whole-cell configuration of the patch-clamp technique was standard (Hamill et al., 1981). Electrodes were pulled from thick-wall, filamented capillary glass tubing (boroscilicate glass; Sutter Instrument, Novato, CA) using a Flaming-Brown puller (model P-80/PC, Sutter Instrument) and had resistances $\sim 4 \mathrm{M} \Omega$ when filled with $150 \mathrm{~mm}$ salt solution. Fire polish was not necessary for these patch electrodes. The patch-clamp amplifier was an Axopatch 1D (Axon Instruments, Foster City, CA) with an integrated headstage, IHS-1, or a $\mathrm{CV} / 4$ headstage. Whole-cell currents were recorded with a bandwidth from DC to $2 \mathrm{KHz}$ (four pole Bessel filter). The pCLAMP programs (Axon Instruments) were used for on-line data acquisition and off-line analysis on MS-DOS computers equipped with Labmaster interfaces (Scientific Solutions, Inc., Solon, OH). Normal bath solution contained (in $\mathrm{mM}$ ) $\mathrm{NaCl}, 145 ; \mathrm{KCl}, 5 ; \mathrm{CaCl}_{2}, 1.8 ; \mathrm{MgCl}_{2}, 1.0 ;$ HEPES-NaOH, 5 ; $\mathrm{pH} 7.4$. Low- $\mathrm{Na}^{+}$bath solutions contained 10,20 , or $50 \mathrm{~mm} \mathrm{NaCl}$ and 135 , 125 , or $95 \mathrm{~mm}$ tetraethylammonium chloride, respectively, plus (in mM) $\mathrm{KCl}, 5 ; \mathrm{CaCl}_{2}, 1.8 ; \mathrm{MgCl}_{2}, 1.0 ; \mathrm{HEPES}, 5 ; \mathrm{pH} 7.4$, adjusted with tetraeth- ylammonium hydroxide. For recording $\mathrm{Na}^{+}$currents, pipette filling solutions contained $10 \mathrm{~mm} \mathrm{NaCl}$ and $120 \mathrm{~mm} \mathrm{CsF}$ for 145,50 , or $20 \mathrm{~mm}$ external $\mathrm{Na}^{+}$and $5 \mathrm{mM} \mathrm{NaCl}$ and $125 \mathrm{~mm} \mathrm{CsF}$ for $10 \mathrm{mM} \mathrm{Na}^{+}$plus 1.0 mм $\mathrm{MgCl}_{2}$, 5 mм EGTA, 5 mм HEPES, pH 7.2, adjusted with CsOH. For recording $\mathrm{K}^{+}$currents, the pipette filling solution contained $135 \mathrm{mM}$ $\mathrm{KCl}, 10 \mathrm{~mm} \mathrm{NaCl}, 5 \mathrm{~mm}$ EGTA, $5 \mathrm{~mm}$ HEPES, $\mathrm{pH}$ 7.2, adjusted with $\mathrm{KOH}$. Bath solutions ( 145 or $10 \mathrm{~mm} \mathrm{Na}{ }^{+}$) with or without tetrodotoxin were perfused onto the cell through polyethylene tubing with an inner diameter of $0.28 \mathrm{~mm}$, which is 5-30 times larger than the size of cells used in our experiments. Temperature was $21-23^{\circ} \mathrm{C}$.

$\mathrm{Na}^{+}$currents recorded in low external $\mathrm{Na}^{+}$could be converted to a value expected for $145 \mathrm{~mm} \mathrm{Na}{ }^{+}$with the relation $i=\gamma\left(V-V_{\mathrm{Na}}\right)$ where $i$ and $\gamma$ are the single-channel current and conductance, respectively, and $V_{\mathrm{Na}}$ is the $\mathrm{Na}^{+}$Nernst potential, based on the single-channel data from Yamamoto et al. (1984). For example, at $-10 \mathrm{mV}$, the peak of the macroscopic current-voltage $(I / V)$ relation, $\gamma$ would be $\sim$ sevenfold higher ( $\sim 13 \mathrm{pS}$; Yamamoto et al., 1984) and $V-V_{\mathrm{Na}}$ would be $\sim$ twofold higher in $145 \mathrm{mM} \mathrm{Na}^{+}$than in $10 \mathrm{mM} \mathrm{Na}^{+}$.

As previously reported by several investigators (Fenwick et al., 1982; Marty and Neher, 1983; Fernandez et al., 1984), we observed that kinetics of whole-cell $\mathrm{Na}^{+}$currents (steady-state activation and inactivation, and inactivation time constants as functions of voltage) in $\mathrm{CHO}$ cells and ventricular myocytes had a time-dependent negative shift of up to $10 \mathrm{mV}$ along the voltage axis. This shift approached a steadystate value $\sim 2$ min after the whole-cell mode was established. The " $t$ $=0$ " and " $t>0$ " data under Results refer to data obtained just after the whole-cell mode was established or when the negative shift reached steady-state values, respectively. Correction for $t>0$ data relative to $t$ $=0$ data was made, when needed, by shifting $t>0$ curves along the voltage axis with values as specified in Results.

We used a nonlinear least-square curve-fitting routine (SIGMAPLot 4.0, Jandel Scientific, Corte Madera, CA) to fit $\mathrm{Na}^{+}$current kinetics to the following equations: $G / G_{\max }=1 /\left\{1+\exp \left[-\left(V-V_{1 / 2}\right) / k\right]\right\}^{3}$ for activation, $I / I_{\max }=1 /\left\{1+\exp \left[\left(V-V_{1 / 2}\right) / k\right]\right\}$ for inactivation, and $\tau=$ $\tau_{a}+\exp \left[-\left(V-V_{o}\right) / V_{e}\right]$ (in msec) for the inactivation time constant; $V$ is voltage, $k$ is a slope factor, $V_{1 / 2}$ is half-maximal voltage, $\tau_{a}$ is an asymptotic inactivation time constant, $V_{e}$ is the $e$-fold voltage, and $V_{v}$ is a voltage defined by $\exp \left(V_{o} / V_{e}\right)($ in msec $)=\tau(V=0)-\tau_{a} . G / G_{\max }=$ $\left(I_{\text {peak }} / I_{o}\right) /\left(V-V_{\mathrm{Na}}\right)$ was determined from the peak current-voltage $(I /$ V) curve, where $I_{\text {peak }}$ is the peak $\mathrm{Na}^{+}$current at a given voltage, $I_{o}$ is the maximal peak current, $V$ is the test potential, and $V_{\mathrm{Na}}$ is the $\mathrm{Na}^{+}$Nernst potential. Steady-state inactivation was obtained with $28 \mathrm{msec}$ prepulses to a $12 \mathrm{msec}$ lest pulse at $-10 \mathrm{mV}$. Holding potential was $-100 \mathrm{mV}$. The interval between successive episodes was 4 sec. Inactivation time constants were obtained by fitting the decay phase of $\mathrm{Na}^{+}$currents to a single exponential.

\section{Results}

\section{Expression of $\mathrm{IIA} \mathrm{Na}^{+}$channels in mammalian cell lines}

We have used a VV vector system to study expression of the $\alpha$-subunit of the IIA $\mathrm{Na}^{+}$channel in several mammalian cell types. It should be noted that we have used the M860 variant of the rat IIA cDNA clone (Auld et al., 1990). This construct encodes the neutral leucine at amino acid position 860 and, when expressed in oocytes, shows a current-voltage $(I / V)$ curve identical to that of $\mathrm{Na}^{+}$channels encoded by rat brain mRNA. As summarized in Table 1, 16-72 hr after infection with vTF7-3 and lipofection with pTM1NaIIA (see Materials and Methods), $\sim 60 \%$ of $\mathrm{CHO}$ (CHO-K1) cells expressed a high level of $\mathrm{Na}^{+}$ currents (Fig. $1 B$ ), undifferentiated mouse $\mathrm{BC}_{3} \mathrm{H} 1$ cells (maintained in $20 \%$ serum) expressed $\mathrm{Na}^{+}$currents poorly, and mouse Ltk ${ }^{-}$cells did not show any detectable $\mathrm{Na}^{+}$currents. However, the expression of $E$. coli $\beta$-galactosidase, assayed by Xgal staining, was comparable (40-90\%) in these three types of cells following infection with vTF7-3 and pTM1 LacZ, which carries the $\beta$-galactosidase gene (see Materials and Methods). $\mathrm{CHO}$ cells had small, endogenous $\mathrm{Na}^{+}$currents, which peaked at $+10 \mathrm{mV}$ (Fig. $2 A$; see Table 1 for peak current amplitudes) and were 
sensitive to TTX. Because so little is known about the molecular biology, physiology, and pharmacology of hamster $\mathrm{Na}^{+}$channels, we have not characterized the endogenous $\mathrm{CHO} \mathrm{Na}{ }^{+}$channels more completely. Endogenous $\mathrm{Na}^{+}$currents that peak at +5 to $+10 \mathrm{mV}$ have also been detected in CHO cells by $\mathrm{T}$. Scheuer and W. A. Catterall (personal communication) and by R. B. Rogart (personal communication). Endogenous $\mathrm{Na}^{+}$currents were detected neither from undifferentiated $\mathrm{BC}_{3} \mathrm{H} 1$ cells nor from Ltk- cells (Table 1), although $\mathrm{BC}_{3} \mathrm{H} 1$ cells have endogenous delayed rectifier-like $\mathrm{K}^{+}$channels. $\mathrm{CHO}$ cells still expressed $\mathrm{Na}^{+}$channels 1 week after infection/transfection, but the fraction of expressing cells in the cultures decreased, presumably because uninfected cells proliferated while infected cells died.

To test whether the $\mathrm{BC}_{3} \mathrm{H} 1$ and $\mathrm{Ltk}^{-}$cells would express any other ion channels with the infection-transfection strategy, we employed the Shaker $\mathrm{H}_{4} \mathrm{~K}^{+}$channel in experiments designed to match as closely as possible the $\mathrm{Na}^{+}$channel expression conditions. The plasmid used was pTM1KH4 (Hsu et al., unpublished observations). Endogenous A-type $\mathrm{K}^{+}$currents were not detected in any of the three cell types. We observed robust transient $\mathrm{K}^{+}$currents $(200-3000 \mathrm{pA}$ at $+50 \mathrm{mV} ; 4 \mu \mathrm{g}$ of pTM1 KH4 per $35 \mathrm{~mm}$ dish) in 11 of $13 \mathrm{BC}_{3} \mathrm{H} 1$ cells and 7 out of $8 \mathrm{Ltk}^{-}$cells following infection with vTF7-3 and pTM1KH4. The IIA $\mathrm{Na}^{+}$channels and the Shaker $\mathrm{H}_{4} \mathrm{~K}^{+}$channels can be expressed simultaneously in $\mathrm{CHO}$ cells after infection with vTF7-3 and cotransfection with both pTM1NaIIA and pTM1 KH4 (Hsu et al., unpublished observations). In a similar experiment, after Ltk ${ }^{-}$cells were infected with VTF7-3 and cotransfected with both pTM1NaIIA and pTM1KH4 $(3.2 \mu \mathrm{g}$ of pTM1NaIIA and $0.8 \mu \mathrm{g}$ of pTM1KH4 per $35 \mathrm{~mm}$ dish), we observed only transient $\mathrm{K}^{+}$currents $(200-3000 \mathrm{pA}$ at $+50 \mathrm{mV}$ ) in 4 of 11 cells, but not $\mathrm{Na}^{+}$currents. The lower percentage of Ltk $^{-}$cells expressing $\mathrm{K}^{+}$channels in this experiment than in experiments with pTM $1 \mathrm{KH} 4$ alone probably arises from the fivefold lower amount of pTM1KH4 used rather than from suppression of $\mathrm{K}^{+}$channel synthesis by the $\mathrm{Na}^{+}$channel plasmid. Thus, the failure of expression is a characteristic of this $\mathrm{Na}^{+}$ channel, and not of ion channels in general.

In $\mathrm{CHO}$ cells, the expressed IIA $\mathrm{Na}^{+}$channels could be readily distinguished from the endogenous $\mathrm{Na}^{+}$channels by several criteria. First, the peak current-voltage $(I / V)$ curve of IIA $\mathrm{Na}^{+}$ currents reached a maximum at $\sim-10 \mathrm{mV}$, which was $\sim 20$ $\mathrm{mV}$ more negative than that of the endogenous currents (Fig. $2 A$ ). Also, the IIA $\mathrm{Na}^{+}$current had a steeper voltage dependence of activation than the endogenous current (Fig. $2 A$ and captions to Figs. 2, 6). Second, the IIA Na+ currents were 10-100-fold larger than the endogenous $\mathrm{Na}^{+}$currents when recorded in 145 mm external $\mathrm{Na}^{+}$(Table 1). In $145 \mathrm{mM} \mathrm{Na}^{+}$, the IIA $\mathrm{Na}^{+}$currents were typically larger than $5 \mathrm{nA}$, too large for proper voltageclamp fidelity. To solve this problem, we recorded $\mathrm{Na}^{+}$currents in reduced external $\mathrm{Na}^{+}$. In external $\mathrm{Na}^{+}$concentrations of 20 mм or lower, there were no detectable endogenous $\mathrm{Na}^{+}$currents. In $10 \mathrm{~mm}$ external $\mathrm{Na}^{+}$, the IIA $\mathrm{Na}^{+}$currents were still as large as $\sim 1 \mathrm{nA}$ with a mean of $586 \pm 204 \mathrm{pA}$ (or a current density of $47 \pm 17 \mathrm{pA} / \mathrm{pF}$ for a cell capacitance of $12.5 \pm 0.21 \mathrm{pF}$; mean \pm SEM, four cells) and had the same activation and inactivation kinetics as in $145 \mathrm{~mm}$ external Na${ }^{+}$(Fig. 2B).

The IIA $\mathrm{Na}^{+}$currents expressed in CHO cells were reduced to undetectable levels by $200 \mathrm{nM}$ TTX (three cells). In the presence of $90 \mathrm{nM}$ TTX, $\mathrm{Na}^{+}$currents were reduced to $\sim 10 \%$ of the control level, indicating an apparent dissociation constant, $K_{d}$,
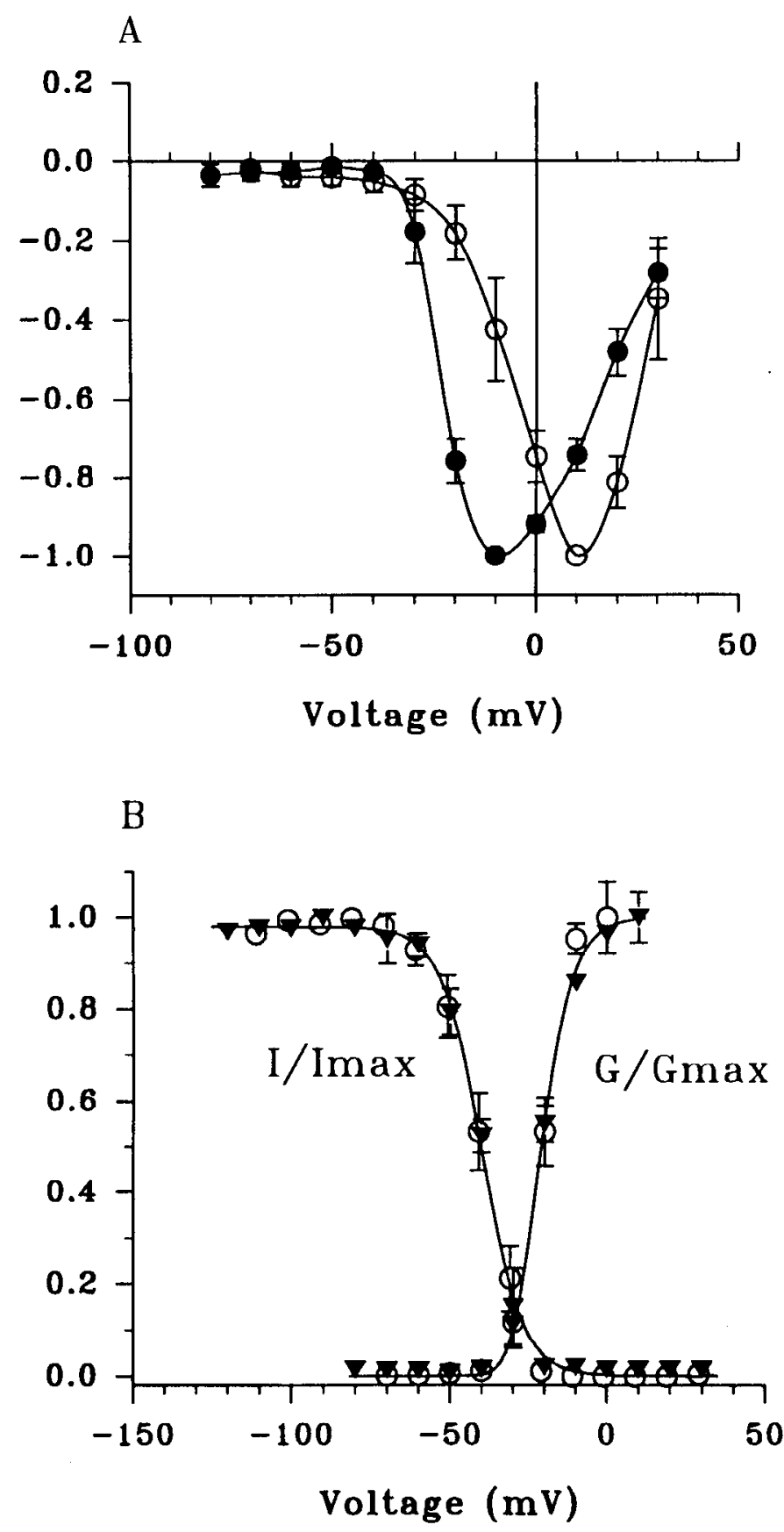

Figure 2. Kinetic properties of the IIA $\mathrm{Na}^{+}$channel expressed in $\mathrm{CHO}$ cells. $A$, Normalized peak $I / V$ curves $(t=0$ data, mean \pm SEM; see Materials and Methods for definitions of $t=0$ and $t>0$ data) for the IIA $\mathrm{Na}^{+}$currents in CHO cells infected with vTF7-3 and transfected with pTM1NaIIA (solid circles; four cells) or with pTM1LacZ (open circles; 4 cells), recorded in $145 \mathrm{~mm} \mathrm{Na}{ }^{+}$. Continuous lines are smooth curves through the data points with no theoretical significance. $B$, IIA $\mathrm{Na}^{+}$channel kinetics at two external $\mathrm{Na}^{+}$concentrations: activation $(G /$ $G_{\max } ; t=0$ data, mean $\pm \mathrm{SEM}$; four cells each for $10 \mathrm{mM}$ and $145 \mathrm{mM}$ $\mathrm{Na}^{+}$solutions) and inactivation $\left(I / I_{\text {max }} ; t>0\right.$ data, mean $\pm \mathrm{SEM}$; four cells for $10 \mathrm{mM} \mathrm{Na}{ }^{+}$and two cells for $145 \mathrm{~mm} \mathrm{Na}{ }^{+}$). A time-dependent shift of $-9 \mathrm{mV}$ for inactivation curve obtained at $t>0$ is corrected here relative to the $t=0$ data (see Materials and Methods). The solid lines are the best fits of the pooled data (obtained in both $10 \mathrm{~mm}$ and $145 \mathrm{mM} \mathrm{Na}^{+}$solutions) to appropriate equations (see Materials and Methods) with $k=6.0 \pm 0.3 \mathrm{mV}$ and $V_{1 / 2}=-29.2 \pm 0.5 \mathrm{mV}$ (eight cells) for activation and $k=6.2 \pm 0.2 \mathrm{mV}$ and $V_{1 / 2}=-39.4 \pm 0.3 \mathrm{mV}$ (six cells) for inactivation. 
Figure 3. TTX sensitivity of $\mathrm{Na}^{+}$currents in ventricular myocytes infected with VTF7-3 and transfected with pTMINaIIA. $A$, A ventricular myocyte that expressed TTX-resistant, endogenous $\mathrm{Na}^{+}$currents $(10 \%$ block by $90 \mathrm{nM}$ TTX). $B$, A ventricular myocyte that expressed TTX-sensitive $\mathrm{Na}^{+}$currents ( $80 \%$ block by 90 nм TTX). 1 , Control solution $(10 \mathrm{~mm} \mathrm{Na}) ; 2$, control solution plus $90 \mathrm{nM}$ TTX; 3 , wash with the control solution. Holding potential, $-100 \mathrm{mV}$; test potential, $-20 \mathrm{mV}$. C, The ratio of peak $\mathrm{Na}^{+}$currents recorded with and without 90 nM TTX as a function of test potential from a holding potential of $-100 \mathrm{mV}$. The interval between test pulses was $4 \mathrm{sec}$. The halfblock concentration, $K_{d}$ (mean $\pm \mathrm{SEM}$, averaged across the voltage range), for TTX block is indicated on the right. Different symbols are from different individual cells, except that the solid triangles represent an average of data from six myocytes (four cells transfected with pTM 1 NaIIA and two cells transfected with pTM1LacZ).
A

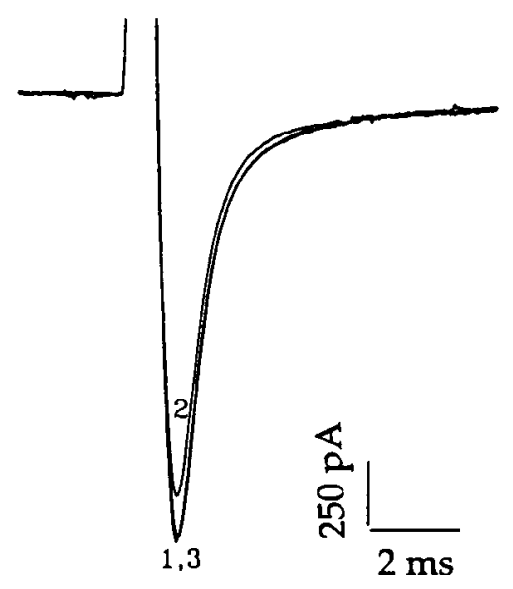

C

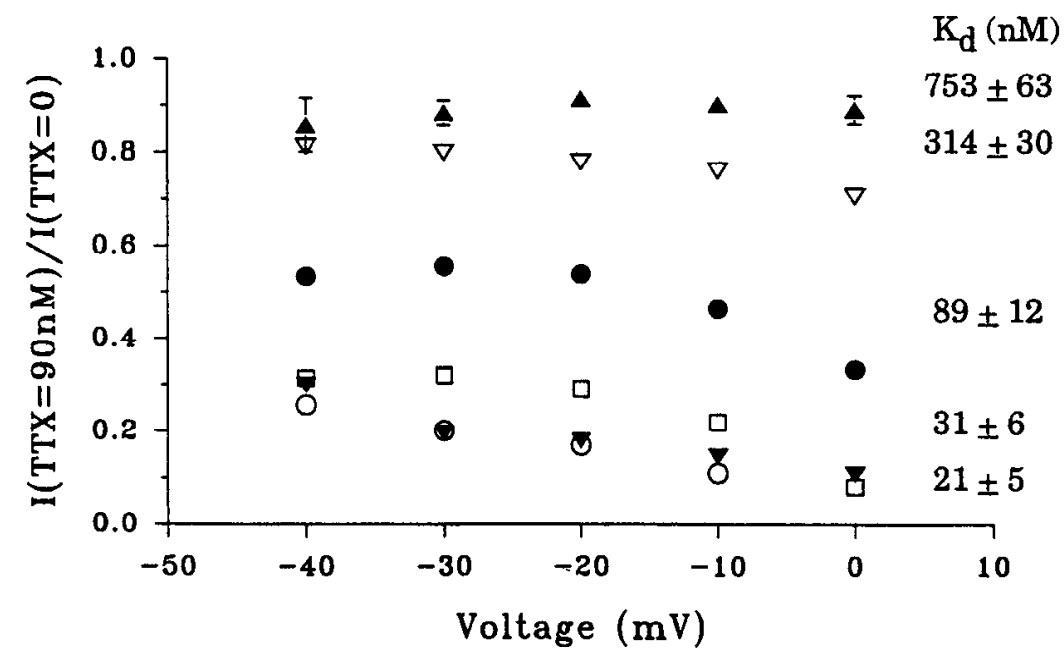

$\mathrm{B}$

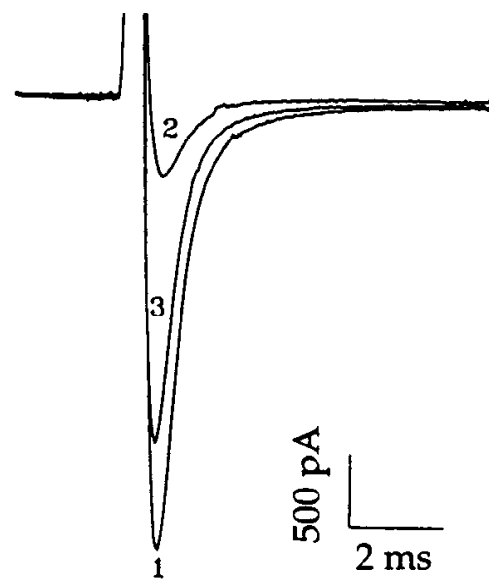

Table 1. Expression of the IIA $\mathrm{Na}^{+}$channel in cell lines

\begin{tabular}{llllcc} 
& & \multicolumn{2}{c}{$\begin{array}{c}\text { Number } \\
\text { of exper- } \\
\text { iments }\end{array}$} & $n / N$ & \multicolumn{2}{c}{ Peak $I_{\mathrm{Na}}(\mathrm{pA})$} & Mean \pm \\
\cline { 5 - 6 } Cells & Samples & 7 & $38 / 67(57 \%)$ & $300->10,000$ & $\sim 5000$ \\
CHO & pTM1NaIIA + vTF7-3 & 7 & $0 / 12(0 \%)$ & $30-350$ & $133 \pm 31$ \\
& pTM1LacZ + vTF7-3 & 1 & $0 / 13(0 \%)$ & $0-213$ & $33 \pm 15$ \\
& pTM1NallA & 1 & $0 / 28(0 \%)$ & $0-85$ & $30 \pm 5$ \\
& Control & 2 & $2 / 19(11 \%)$ & $<100$ & - \\
BC $_{3} \mathrm{H} 1$ & pTM1NaIIA + vTF7-3 & 3 & $0 / 12(0 \%)$ & 0 & 0 \\
& Control & 2 & $0 / 54(0 \%)$ & 0 & 0 \\
Ltk $^{-}$ & pTM1NaIIA + vTF7-3 & 3 & $0 / 14(0 \%)$ & 0 & 0
\end{tabular}

$n / N, n$ cells expressing the IIA Na ${ }^{+}$channels out of $N$ cells recorded 16-72 $\mathrm{hr}$ after infection and/or transfection; Peak $I_{\mathrm{Na}}(\mathrm{pA})$, the maximal peak $\mathrm{Na}^{+}$currents (at -10 to $-20 \mathrm{mV}$ ) recorded in $145 \mathrm{mM}$ external $\mathrm{Na}^{+}$, except that in CHO cells infected with $v T F 7-3$ and transfected with pTM1NaIIA, peak $I_{N a}$ values were measured in $10,20,50$, or $145 \mathrm{~mm}$ external $\mathrm{Na}^{+}$, and the values obtained in low $\mathrm{Na}^{+}$were converted to values expected for $145 \mathrm{~mm} \mathrm{Na}^{+}$(see Materials and Methods). 


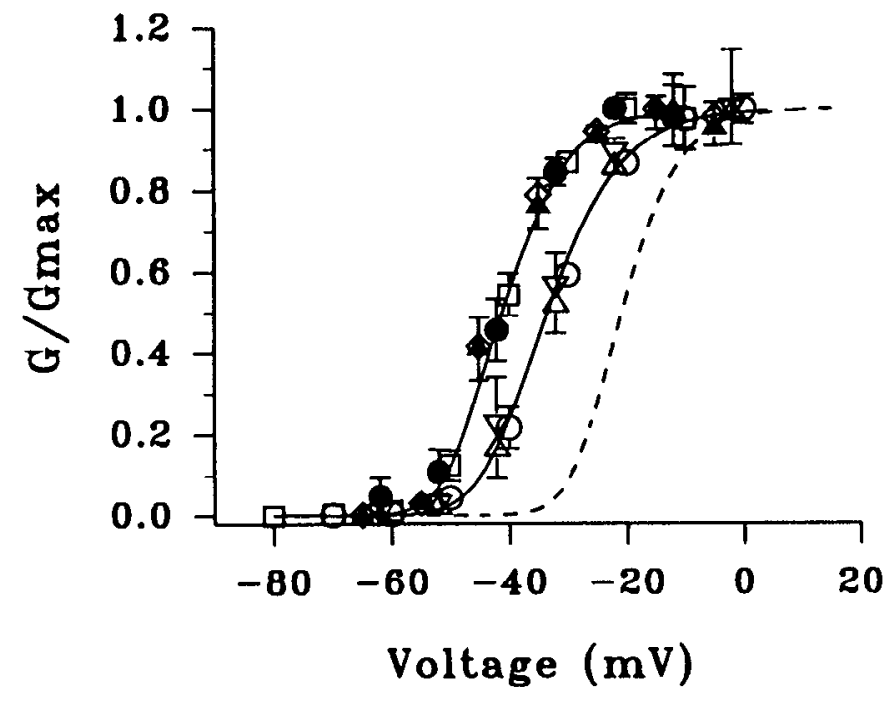

Figure 4. Voltage dependence of activation $\left(G / G_{\max }\right)$ for $\mathrm{Na}^{+}$currents in ventricular myocytes. Data (mean $\pm \mathrm{SEM}$ ) were obtained in the presence (solid symbols) or absence (open symbols) of 90 nM TTX. For TTX-sensitive $\mathrm{Na}^{+}$currents in myocytes transfected with pTM1NaIIA and infected with vTF7-3, $t>0$ data include open triangles for TTX $=0$ (four cells), solid circles for TTX $=90 \mathrm{nM}$ (three cells), and open inverted triangles for wash (two cells). The time-dependent shift of -9 $\mathrm{mV}$ for $t>0$ data is corrected relative to the $t=0$ data (open circles; five cells in TTX $=0$ ). For the TTX-resistant currents in myocytes transfected with pTM1NaIIA and infected with vTF7-3, $t>0$ data include open diamonds for TTX $=0$ and solid triangles for TTX $=90$ nM (three cells, five to seven observations). The time-dependent shift of $-5 \mathrm{mV}$ is corrected relative to the $t=0$ data (not shown). The open squares are $t=0$ data obtained from mock-transfected myocytes (10 cells). The solid lines are the best fits to data with $k=7.5 \pm 0.3 \mathrm{mV}$ and $V_{1 / 2}=-43.6 \pm 0.4 \mathrm{mV}$ for TTX-sensitive currents in the absence of TTX, and with $k=6.5 \pm 0.3 \mathrm{mV}$ and $V_{1 / 2}=-49.7 \pm 0.5 \mathrm{mV}$ for endogenous currents in mock-transfected myocytes. The dashed line is the activation curve of IIA Na ${ }^{+}$currents in CHO cells as shown in Figure $2 B$. of $\sim 10 \mathrm{nM}$ for TTX, which is in close agreement with the $K_{d}$ values reported previously (Scheuer et al., 1990).

\section{Expression of the IIA $\mathrm{Na}^{+}$channel in ventricular myocytes}

To test whether the brain $\mathrm{Na}^{+}$channel would become resistant to TTX in heart cells by cell-specific posttranslational modifications, primary cultures of neonatal rat ventricular myocytes were infected with vTF7-3 and transfected with pTM1NaIIA. TTX at a concentration of $90 \mathrm{~nm}$ blocked $\sim 10 \%$ of $\mathrm{Na}^{+}$currents in $25 \%$ (4 out of 16 ) of myocytes, but blocked $40-85 \%$ of $\mathrm{Na}^{+}$ currents in another $63 \%$ (10 out of 16) of myocytes (Fig. 3). The action of TTX was nearly independent of test voltage (Fig. $3 C$ ). In myocytes infected with vTF7-3 and transfected with pTM1LacZ ("mock-transfected"), we observed only TTX-resistant $\mathrm{Na}^{+}$currents, which were blocked by $\sim 10 \%$ with $90 \mathrm{nM}$ TTX, corresponding to a $K_{d}$ of $\sim 800 \mathrm{~nm}$ (Fig. $3 C$ ), similar to $K_{d}$ values previously reported for cardiac $\mathrm{Na}^{+}$currents (Catterall and Coppersmith, 1981; Cohen et al., 1981; Krafte et al., 1991). The straightforward interpretation of these data is that the myocytes with increased TTX sensitivity expressed both TTXsensitive and TTX-resistant $\mathrm{Na}^{+}$channels, corresponding to (1) brain IIA channels that retained their TTX sensitivity and (2) endogenous, TTX-insensitive, cardiac $\mathrm{Na}^{+}$channels. That $25 \%$ of infected cells failed to express TTX-sensitive channels is consistent with our previous experience with VV expression of ion channels (Leonard et al., 1989; Karschin et al., 1991; see also Table 1) and is due to cells with a relatively low level of expression of the exogenous channels.

In the myocytes expressing $\mathrm{TTX}$-sensitive $\mathrm{Na}^{+}$currents, the voltage dependence of $\mathrm{Na}^{+}$current activation was intermediate between those of the IIA current expressed in C.HO cells and of the endogenous $\mathrm{Na}^{+}$currents in mock-transfected myocytes (Fig. 4). In the presence of $90 \mathrm{~nm}$ TTX, the activation of the remaining

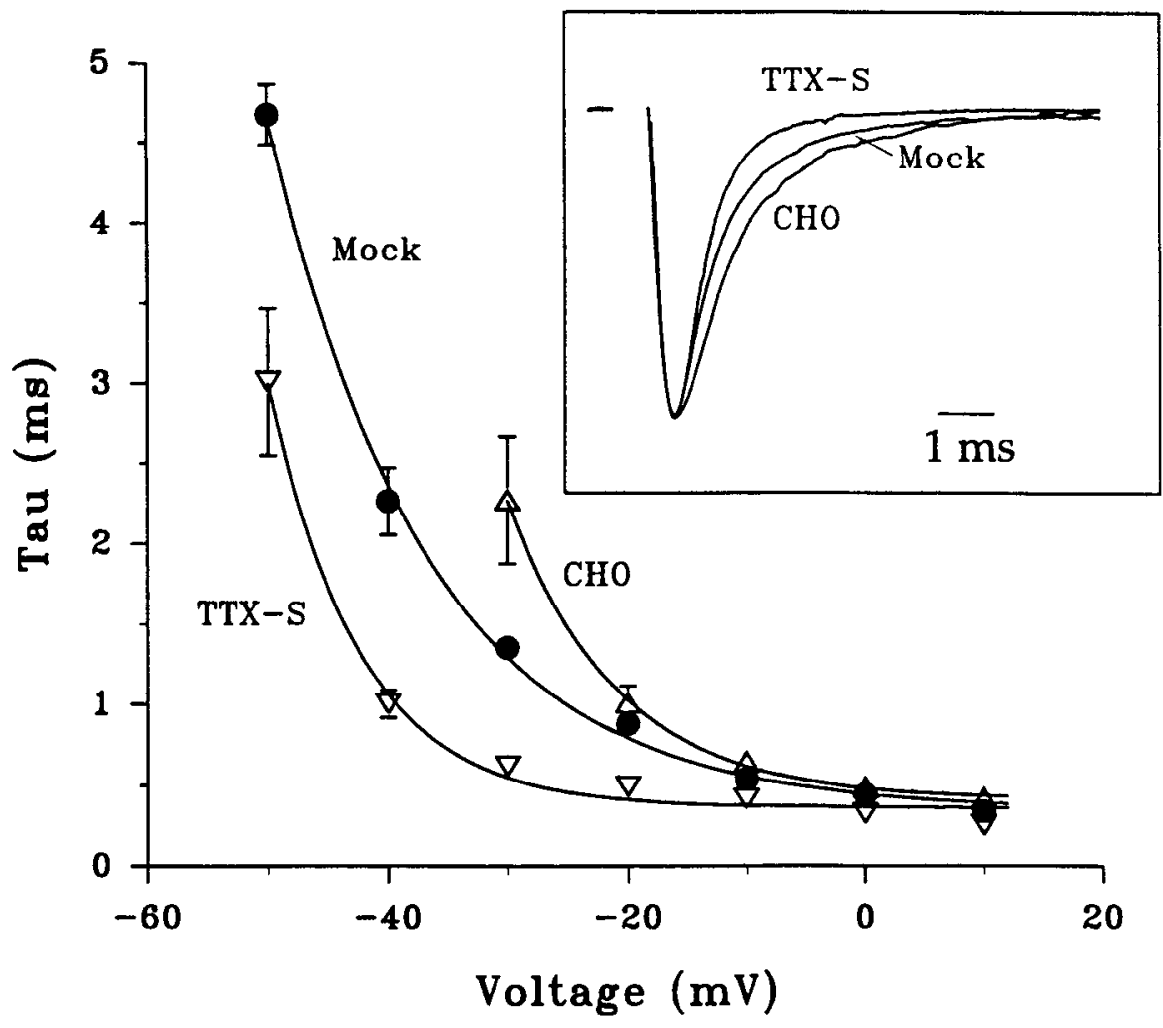

Figure 5. Inactivation time constants $\left(t>0\right.$ data, mean $\perp$ SEM) of $\mathrm{Na}^{+}$currents from the pTM 1 NaIIA-transfected $\mathrm{CHO}$ cells ( $\mathrm{CHO}$, open triangles; four cells and 13 observations), the pTM1NaIIA-transfected ventricular myocytes that express TTX-sensitive $\mathrm{Na}^{+}$currents ( $T T X-S$, inverted open triangles; six cells and 14 observations), and the pTM1LacZ-transfected myocytes (Mock, solid circles; nine cells and 14 observations). The inset shows the waveforms at a test potential of -20 $\mathrm{mV}$. Holding potential, $-100 \mathrm{mV}$; external $\mathrm{Na}^{+}, 10 \mathrm{~mm}$. The $t>0$ data shown here were not corrected relative to the $t=0$ data (not shown), which have similar characteristics. The $t>0$ data had time-dependent shifts of $-7 \mathrm{mV}(\mathrm{CHO})$, $-5 \mathrm{mV}$ (Mock), and $-10 \mathrm{mV}$ (TTX$S)$, respectively, relative to the $t=0$ data. Solid lines are the best fits of data to an exponential function (see Materials and Methods) with parameters $\tau_{a}$ $=0.42 \pm 0.02 \mathrm{msec}, V_{o}=-24.4 \pm 0.4$ $\mathrm{mV}$, and $V_{e}=9.0 \pm 0.4 \mathrm{mV}$ for $\mathrm{CHO}$; $\tau_{a}=0.35 \pm 0.06 \mathrm{msec}, V_{o}=-30.7 \pm$ $1.2 \mathrm{mV}$, and $V_{e}=13.2 \pm 0.7 \mathrm{mV}$ for Mock; and $\tau_{a}=0.36 \pm 0.05 \mathrm{msec}, V_{o}$ $--42.7 \pm 0.8 \mathrm{mV}$, and $V_{e}=7.6 \pm$ $0.8 \mathrm{mV}$ for $T T X-S$. 

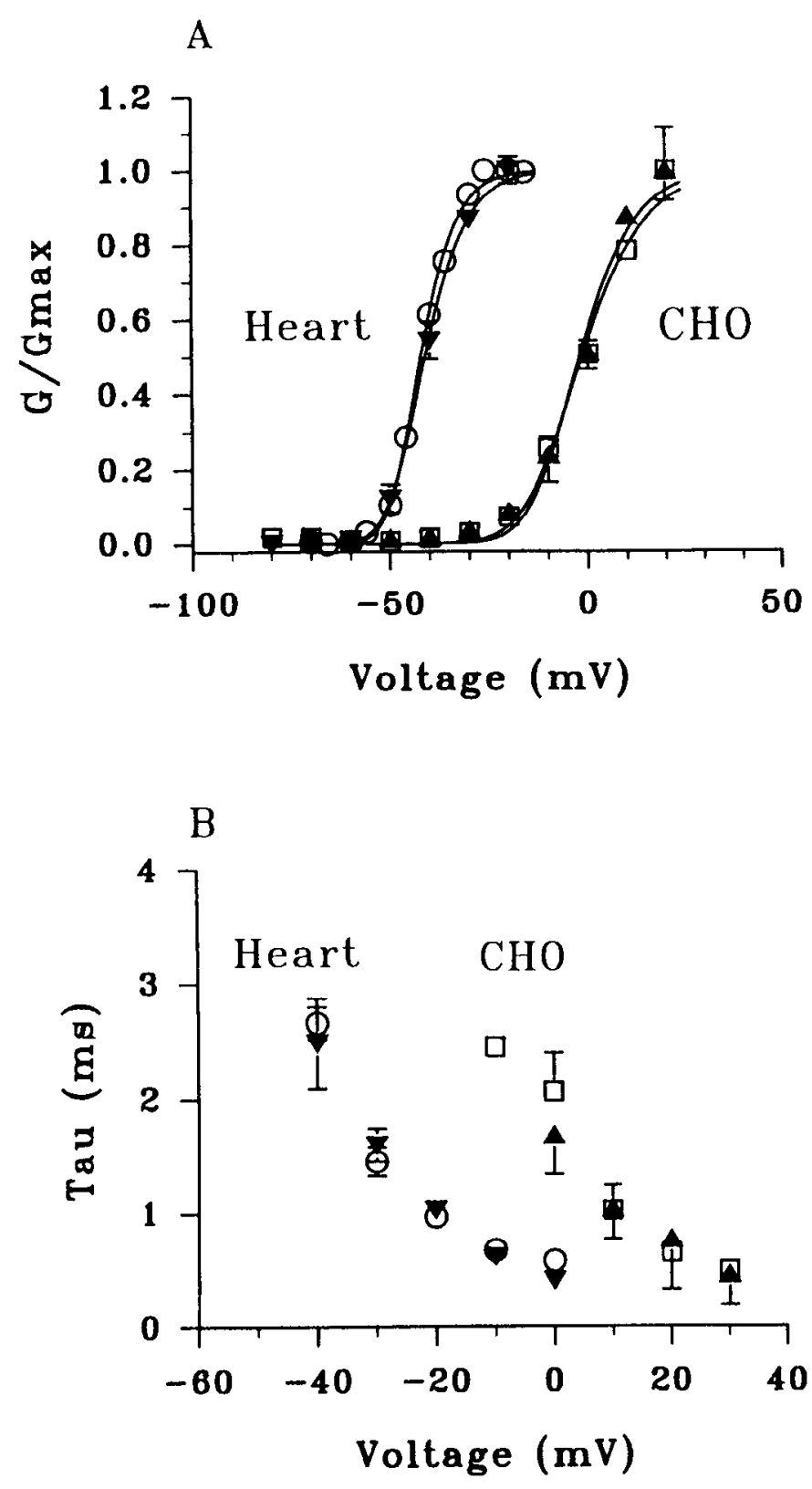

Figure 6. Effects of mock transfection on endogenous $\mathrm{Na}^{+}$channel kinetics in $\mathrm{CHO}$ cells and in ventricular myocytes (Heart). Open and solid symbols are for control cells and mock-transfected cells, respectively. A, Activation $\left(G / G_{\max }\right.$, mean \pm SEM). Solid lines are the best fits to the data with the following parameters for CHO cells: $k=9.7 \pm$ $0.8 \mathrm{mV}$ and $V_{1 / 2}=-14.7 \pm 1.2 \mathrm{mV}$ (control, six cells); $k=8.6 \pm 0.9$ $\mathrm{mV}$ and $V_{1 / 2}=-13.6 \pm 1.5 \mathrm{mV}$ (mock-transfected, four cells); and with the following parameters for ventricular myocytes: $k=5.5 \pm 0.2 \mathrm{mV}$ and $V_{1 / 2}=-49.5 \pm 0.3 \mathrm{mV}$ (control, two cells); $k=6.5 \pm 0.3 \mathrm{mV}$ and $V_{1 / 2}=-49.7+0.5 \mathrm{mV}$ (mock-transfected, 10 cells). $B$. Inactivation time constants (mean $\pm \mathrm{SEM}$ ). All data were obtained at $t=0$; external $\mathrm{Na}^{+}, 145 \mathrm{~mm}$ for $\mathrm{CHO}$ cells and $10 \mathrm{~mm}$ for ventricular myocytes (Heart).

$\mathrm{Na}^{+}$currents shifted to the left along the voltage axis and overlapped the plot for the endogenous, cardiac $\mathrm{Na}^{+}$currents. This negative shift was reversed when TTX was removed from the recording chamber. No such shift in activation was observed for myocytes expressing only TTX-resistant $\mathrm{Na}^{+}$currents. This result is as expected if $90 \mathrm{nM}$ TTX blocked $90 \%$ of the brain $\mathrm{Na}^{+}$channels and left $90 \%$ of endogenous, TTX-resistant car- diac channels unaffected in the myocytes transfected with the IIA $\mathrm{Na}^{+}$channels.

Despite the qualitatively consistent picture presented by these data, further analysis shows that the infected-transfected myocytes are not simply gaining a proportion of $\mathrm{Na}^{+}$channels with the same characteristics as those expressed in CHO cells. For instance, let the activation curves in Figure 4 be named as $A_{\text {heart }}(V), A_{\mathrm{IT}}(V)$, and $A_{\mathrm{CHO}}(V)$ for the currents in mock-transfected ventricular myocytes, infected-transfected cardiac cells, and infected-transfected $\mathrm{CHO}$ cells, respectively. We were unable to find a voltage-independent parameter $f$, corresponding to the fraction of new IIA $\mathrm{Na}^{+}$channels in infected-transfected myocytes, that satisfied the relation $A_{\mathrm{IT}}(V)=\mathrm{f} A_{\mathrm{CHO}}(V)+(1-$ f) $A_{\text {heart }}(V)$. The activation relation for the infected-transfected myocytes is steeper than would be predicted by such a relation.

We also devoted considerable analysis to the question of whether the actual $\mathrm{Na}^{+}$current waveforms in the infected-transfected myocytes could be described as a similar weighted average of the waveforms for the mock-transfected cardiac cells and those of the infected-transfected $\mathrm{CHO}$ cells. The waveforms that are TTX-sensitive in the infected-transfected cardiac cells inactivated faster than would be expected from such a relation. These anomalies are clearest in infected-transfected cardiac cells, as shown by the data represented by inverted triangles in Figure 5 , in which nearly all of the current is TTX sensitive and therefore presumably contributed by newly expressed IIA channels.

The TTX-sensitive $\mathrm{Na}^{+}$currents in myocytes transfected with the $\alpha$-subunit of the brain IIA $\mathrm{Na}^{+}$channel (pTM1NaIIA plus vTF7-3) inactivated faster than the IIA $\mathrm{Na}^{+}$currents expressed in CHO cells (Fig. 5). The inactivation time course of the cardiac $\mathrm{Na}^{-1}$ currents in mock-transfected myocytes was intermediate between those of the IIA $\mathrm{Na}^{+}$currents in $\mathrm{CHO}$ cells and of the TTX-sensitive $\mathrm{Na}^{+}$currents. The most straightforward interpretation of these data is that the IIA $\mathrm{Na}^{+}$channel expresses with different voltage-dependent gating properties in $\mathrm{CHO}$ and cardiac cells.

\section{Effects of infection-transfection on endogenous $\mathrm{Na}^{+}$currents in $\mathrm{CHO}$ and cardiac cells}

To test whether viral proteins produced by vTF7-3 in infected cells would affect the $\mathrm{Na}^{+}$channel gating kinetics, endogenous $\mathrm{Na}^{+}$currents recorded in $\mathrm{CHO}$ cells and ventricular myocytes under control conditions (without infection and transfection) were compared with the $\mathrm{Na}^{+}$currents in mock-transfected cells. As shown in Figure 6, mock transfection did not alter the endogenous $\mathrm{Na}^{+}$channel kinetics in either $\mathrm{CHO}$ cells or ventricular myocytes. In mock-transfected $\mathrm{CIIO}$ cells, however, endogenous $\mathrm{Na}^{+}$currents increased by approximately fourfold (Table 1). Like control ventricular myocytes, myocytes after infectiontransfection also displayed 100-500 pA L-type $\mathrm{Ca}^{2+}$ currents in $1.8 \mathrm{~mm}$ external $\mathrm{Ca}^{2+}$ and were able to contract spontaneously.

\section{Discussion}

In this study, we have used a VV system for the functional expression of a $\mathrm{Na}^{+}$channel cDNA in mammalian cells, including primary cells. The system is efficient in two senses. (1) Expression occurs in a high proportion $(\sim 60 \%)$ of cells in a culture. (2) Channel density is rather high. The average current of $600 \mathrm{pA}$ per $\mathrm{CHO}$ cell in $10 \mathrm{mM} \mathrm{Na}^{+}$would correspond, in $145 \mathrm{mM} \mathrm{Na}^{+}$, to $\sim 9 \mathrm{nA}$ (see Materials and Methods). This level is 60 -fold higher than achieved with stably transfected cells by Scheuer et al. (1990) and, for an average cell capacitance of 12.5 
$\mathrm{pF}$ and a specific capacitance of $1 \mu \mathrm{F} / \mathrm{cm}^{2}$, corresponds to $\sim 7$ channels per $\mu \mathrm{m}^{2}$. Because not all channels open simultaneously, a better estimate might be $\sim 10$ channels per $\mu \mathrm{m}^{2}$. This density is similar to $\mathrm{Na}^{+}$channel densities observed in central neurons (3-5 channels $/ \mu \mathrm{m}^{2}$, Huguenard et al., $1988 ; 5-10$ channels $/ \mu \mathrm{m}^{2}$, Sah et al., 1988). Recent observations report similar high densities in other mammalian expression systems (Scheuer et al., 1991; Ukomadu et al., 1991). We have used this method to examine three questions of present interest.

\section{Control of $\mathrm{IIA} \mathrm{Na}^{+}$channel expression at posttranslational levels}

First, the data show that the level of expression of IIA $\mathrm{Na}^{+}$ channel on the plasma membrane is cell type dependent (Table 1). The IIA Na ${ }^{+}$channel expressed efficiently in $\mathrm{CHO}$ cells and ventricular myocytes, poorly in undifferentiated $\mathrm{BC}_{3} \mathrm{H} 1$ cells, and not at all in Ltk ${ }^{-}$cells. In the VV/T7 expression system, vTF7-3 produces T7 RNA polymerase in the cytoplasm of infected cells (Fuerst et al., 1986). In the pTM1NaIIA plasmid, the IIA $\mathrm{Na}^{\prime}$ channel cDNA contains no 5 ' untranslated region from the genomic sequence and is transcribed under the control of a T7 promoter (see Materials and Methods). Thus, although it would be of interest to have direct measurements on $\mathrm{Na}^{+}$ channel RNA in the cells studied, cell-specific expression differences of the IIA $\mathrm{Na}^{+}$channel are not likely to be controlled at the RNA synthesis level. Because $\mathrm{CHO}$ cells, $\mathrm{BC}_{3} \mathrm{H} 1$ cells, and $\mathrm{Ltk}^{-}$cells all expressed the Shaker $\mathrm{H}_{4} \mathrm{~K}^{+}$channels (for the $\mathrm{K}^{+}$channel expression in $\mathrm{CHO}$ cells, see $\mathrm{Hsu}$ et al., unpublished observations) and $\beta$-galactosidase at comparable levels with the VV/T7 expression vectors (VTF7-3 and PTM1KH4 or pTM1 LacZ), the cell-specific expression of the IIA channel most probably resulted from differences in posttranslational processing that are peculiar to this channel. Such processing may not occur with other channels such as the Shaker $\mathrm{K}^{+}$channel and the skeletal muscle dihydropyridine-sensitive $\mathrm{Ca}^{2+}$ channel, which is roughly as large as the $\mathrm{Na}^{\prime}$ channel but nonetheless expresses in Ltk ${ }^{-}$cells (Perez-Reyes et al., 1989). During biosynthesis in rat neurons, the $\alpha$-subunits of $\mathrm{Na}^{+}$channels are glycosylated at several steps, resulting in a $25 \%$ increase of their molecular weight (Schmidt and Catterall, 1986). Interference with glycosylation affects the expression of functional $\mathrm{Na}^{+}$channels in neuroblastoma cells (Giovanni et al., 1981; Waechter et al., 1983; Negishi and Glick, 1986). Also, the Electrophorus electroplaque $\mathrm{Na}^{+}$channel fails to express in Xenopus oocytes, perhaps because the channel does not acquire necessary glycosylation and hydrophobic moieties necessary for its mature functional form (Thornhill and Levinson, 1987). Our results suggest that posttranslational processing (broadly defined, to include possible association with accessory proteins as well as covalent modifications) may be an additional mechanism influencing cellspecific expression of $\mathrm{Na}^{+}$channels in mammalian cells. Since $\mathrm{CHO}$ and ventricular cells, but not $\mathrm{Ltk}^{-}$and undifferentiated $\mathrm{BC}_{3} \mathrm{Hl}$ cells, express endogenous $\mathrm{Na}^{+}$channels, the existing mechanisms for endogenous $\mathrm{Na}^{+}$channel maturation may be used for the functional expression of heterologous IIA $\mathrm{Na}^{+}$channels. The posttranslational control of $\mathrm{Na}^{+}$channel expression implies that $\mathrm{Na}^{+}$channel gene expression must be coordinated with expression of genes encoding modifying enzymes, subunits, or other proteins necessary for $\mathrm{Na}^{+}$channel maturation. The next step in our studies will be to examine details of possible posttranslational modifications to the $\mathrm{Na}^{+}$channel protein during biosynthesis in the various mammalian cells studied here.
These and similar questions are best approached using antibody probes.

\section{TTX-binding site of brain $\mathrm{Na}^{+}$channels}

Second, the brain IIA $\mathrm{Na}^{+}$channel retains its TTX sensitivity when expressed in CHO cells that have TTX-sensitive endogenous $\mathrm{Na}^{+}$currents, as well as in ventricular myocytes that have TTX-resistant endogenous $\mathrm{Na}^{+}$channels. These results indicate that the TTX-binding site of the IIA $\mathrm{Na}^{+}$channel is not subject to cell-specific posttranslational modifications in mammalian cells. A mutation replacing a glutamate residue by a glutamine at position 387 of the amino acid sequence in the rat brain II $\mathrm{Na}^{+}$channel expressed in Xenopus oocytes renders the channel resistant to TTX (Noda et al., 1989). This observation, results on oocyte expression of cardiac $\mathrm{Na}^{+}$channels (Cribbs et al., 1990; White et al., 1991), and the present independent and complementary result indicate that the TTX-binding site of the brain II (or IIA) $\mathrm{Na}^{+}$channel is conferred by its primary amino acid sequence.

\section{Inactivation time course of the IIA $\mathrm{Na}^{+}$channel}

Third, our analysis showed that the IIA $\mathrm{Na}^{+}$channel has different gating properties when expressed in ventricular myocytes and in $\mathrm{CHO}$ cells. Neither the activation curve nor the waveform of TTX-sensitive $\mathrm{Na}^{+}$currents in myocytes transfected with the IIA channel could be described as a weighted average of the activation curves of the IIA channel in the CHO cells and of the endogenous, cardiac $\mathrm{Na}^{+}$channels (Figs. 4, 5). Because mock transfection did not alter the kinetics of endogenous $\mathrm{Na}^{+}$channels in either CHO cells or ventricular myocytes (Fig. 6), the viral infection and lipofection are unlikely to affect the kinetics of the IIA Na+ channels heterologously expressed in these cells. Furthermore, in Xenopus oocytes injected with vTF7-3 and plasmids carrying the IIA $\mathrm{Na}^{+}$channel cDNA, the kinetics of expressed IIA $\mathrm{Na}^{+}$currents are the same as in oocytes injected with the IIA RNA (Yang et al., 1991). Thus, the different inactivation time course in CHO cells and in ventricular myocytes suggests cell-specific posttranslational processing of the $\alpha$-subunit of IIA $\mathrm{Na}^{+}$channel.

For technical reasons, the time course of macroscopic inactivation provides the most obvious indication of differences in gating properties of $\mathrm{Na}^{+}$channels expressed under various conditions. Thus, earlier studies from this laboratory, using Xenopus oocytes, led to the conclusion that low molecular weight RNA encodes proteins that accelerate macroscopic inactivation (Auld et al., 1988; Krafte et al., 1988, 1990). Although the $\mathrm{Na}^{+}$ channel $\alpha$-subunit encodes "rapid inactivating" $\mathrm{Na}^{+}$currents in the two mammalian cells thus far examined-ventricular myocytes and CHO cells (see also Scheuer et al., 1990)-inactivation is more rapid in ventricular myocytes. It will be of interest to examine these kinetic properties with single-channel measurements.

The specific nature of the posttranslational processing differences in the cell types studied here is not known. $\mathrm{Na}^{+}$channels can be modified by phosphorylation and other second messenger mechanisms as exemplified by the observations that activation of protein kinase $\mathrm{C}$ or G-proteins reduces the IIA $\mathrm{Na}^{+}$currents expressed in Xenopus oocytes (Dascal and Lotan, 1991) or endogenous $\mathrm{Na}^{+}$channels in cardiac myocytes (Schubert et al., 1989) without changing inactivation time course. A different and very likely possibility for cell-specific processing is association of the $\alpha$-subunit with other cellular peptides, related to 
the $\beta$-subunits expressed in brain. Brain $\mathrm{Na}^{+}$channels consist of two $\beta$-subunits ( $36 \mathrm{kDa} \beta_{1}$ and $33 \mathrm{kDa} \beta_{2}$ ) in addition to the $\alpha$-subunit (260 kDa; Messner and Catterall, 1985); skeletal muscle $\mathrm{Na}^{+}$channels consist of one $\beta$-subunit of $38 \mathrm{kDa}$ (Kraner et al., 1985; Casadei et al., 1986; Roberts and Barchi, 1987), although only an $\alpha$-subunit (230-270 kDa) of cardiac $\mathrm{Na}^{+}$channel is purified from chick heart (Lombet and Lazdunski, 1984). Injection of low molecular weight RNA accelerates the inactivation time course of $\mathrm{Na}^{+}$currents in oocytes injected with high molecular weight brain RNA or cloned IIA transcripts (Auld et al., 1988; Krafte et al., 1988, 1990), suggesting that either $\beta$ subunits or other modifying proteins are involved in the brain $\mathrm{Na}^{+}$channel inactivation process, possibly by interacting with the intracellular loop between the third and fourth membrane repeats of the $\mathrm{Na}^{+}$channel $\alpha$-subunit. This loop is one molecular structure involved in $\mathrm{Na}^{+}$channel inactivation, as indicated by effects of deletions in the rat brain II $\mathrm{Na}^{+}$channel (Stuhmer et al., 1989) and of sequence-directed antibodies in skeletal muscle $\mathrm{Na}^{+}$channels (Vassilev et al., 1988).

\section{References}

Auld VJ, Goldin AL, Krafte DS, Marshall J, Dunn JM, Catterall WA, Lester HA, Davidson N, Dunn RJ (1988) A rat brain $\mathrm{Na}^{+}$channel $\alpha$ subunit with novel gating properties. Neuron 1:51-55.

Auld VJ, Goldin AL, Krafte DS, Catterall WA, Lester HA, Davidson N (1990) A neutral amino acid change in segment IIS4 dramatically alters the gating properties of the voltage-dependent sodium channel. Proc Natl Acad Sci USA 87:323-327.

Blondel B, Roijen I, Cheneval JP (1970) Heart cells in culture: a simple method for increasing the proportion of myoblasts. Experientia 27: 356-358.

Casadei JM, Gordon RD, Barchi RL (1986) Immunoaffinity isolation of $\mathrm{Na}^{+}$channels from rat skeletal muscle. Analysis of subunits. J Biol Chem 261:4318-4323.

Catterall WA, Coppersmith J (1981) Pharmacological properties of sodium channels in cultured rat heart cells. Mol Pharmacol 20:533542.

Cohen CJ, Bean BP, Colatsky TI, Tsien RW (1981) Tetrodotoxin block of sodium channels in rabbit Purkinje fibers-interactions between toxin binding and channel gating. J Gen Physiol 78:383-411.

Cribbs LL, Satin J, Fozzard HA, Rogart RB (1990) Functional expression of the rat heart $\mathrm{I} \mathrm{Na}^{+}$channel isoform. Demonstration of properties characteristic of native cardiac $\mathrm{Na}^{+}$channels. FEBS Lett 275:195-200.

Dascal N, Lotan I (1991) Activation of protein kinase C alters voltage dependence of a $\mathrm{Na}^{+}$channel. Neuron 6:165-175.

Elroy-Stein O, Fuerst TR, Moss B (1989) Cap-independent translation of mRNA conferred by encephalomyocarditis virus $5^{\prime}$ sequence improves the performance of the vaccinia virus/bacteriophage T7 hybrid expression system. Proc Natl Acad Sci USA 86:6126-6130.

Fenwick EM, Marty A, Neher E (1982) Sodium and calcium channels in bovine chromaffin cells. J Physiol (Lond) 331:599-635.

Fernandez JM, Fox AP, Krasne S (1984) Membrane patches and whole-cell membranes: a comparison of electrical properties in rat clonal pituitary $\left(\mathrm{GH}_{3}\right)$ cells. J Physiol (Lond) 356:565-585.

Fuerst TR, Niles EG, Studier FW, Moss B (1986) Eukaryotic transientexpression system based on recombinant vaccinia virus that synthesizes bacteriophage T7 RNA polymerase. Proc Natl Acad Sci USA 83:8122-8126.

Giovanni M, Kessel D, Glick MC (1981) Specific monosaccharide inhibition of active sodium channels in neuroblastoma cells. Proc Natl Acad Sci USA 78:1250-1254.

Grubman SA, Cooperman SS, Begley MB, Weintraub JL, Goodman RH, Mandel G (1988) Tissue-specific expression of genes encoding the rat voltage-gated sodium channel. Curr Top Membr Transp 33: $277-288$

Hamill OP, Marty A, Neher E, Sakmann B, Sigworth FJ (1981) Improved patch-clamp techniques for high-resolution current recording from cells and cell-free membrane patches. Pfluegers Arch 391:85100.
Hille B (1984) Ionic channels of excitable membranes. Sunderland, MA: Sinauer.

Huguenard JR, Hamill OP, Prince DA (1988) Developmental changes in $\mathrm{Na}^{+}$conductances in rat neocortical neurons: appearance of a slowly inactivating component. J Neurophysiol 59:778-795.

Kallen RG, Sheng Z-H, Yang J, Chen L, Rogart RB, Barchi RL (1990) Primary structure and cxpression of a sodium channcl characteristic of denervated and immature rat skeletal muscle. Neuron 4:233-242.

Karschin A, Aiyar J, Gouin A, Davidson N, Lester HA (1991) $\mathrm{K}^{+}$ channel expression in primary cell cultures mediated by vaccinia virus. FEBS Lett 278:229-233.

Krafte DS, Snutch TP, Leonard JP, Davidson N, Lester HA (1988) Evidence for the involvement of more than one mRNA species in controlling the inactivation process of rat and rabbit brain $\mathrm{Na}^{+}$channels expressed in Xenopus oocytes. J Neurosci 8:2859-2868.

Krafte DS, Goldin AL, Auld VJ, Dunn RJ, Davidson N, Lester HA (1990) Inactivation of cloned $\mathrm{Na}^{+}$channels expressed in Xenopus oocytes. J Gen Physiol 96:689-706.

Krafte DS, Volberg WA, Dillon K, Ezrin AM (1991) Expression of cardiac $\mathrm{Na}^{+}$channels with appropriate physiological and pharmacological properties in Xenopus oocytes. Proc Natl Acad Sci USA 88: 4071-4074.

Kraner SD, Tanaka JC, Barchi RL (1985) Purification and functional reconstitution of the voltage-sensitive sodium channel from rabbit T-tubular membranes. J Biol Chem 260:6341-6347.

Leonard RJ, Karschin A, Jayashree-Aiyar S, Davidson N, Tanouye MA, Thomas L, Thomas G, Lester HA (1989) Expression of Drosophila Shaker potassium channels in mammalian cells infected with recombinant vaccinia virus. Proc Natl Acad Sci USA 86:7629-7633.

Lombet A, Lazdunski M (1984) Characterization, solubilization, affinity labeling and purification of the cardiac $\mathrm{Na}^{+}$channel using Tityus toxin $\gamma$. Eur J Biochem 141:651-660.

Marty A, Neher E (1983) Tight-seal whole-cell recording. In: Singlechannel recording (Sakmann B, Neher E, eds), pp 107-122. New York: Plenum.

Maue RA, Kraner SD, Goodman RH, Mandel G (1990) Neuronspecific expression of the rat brain type II sodium channel gene is directed by upstream regulatory elements. Neuron 4:223-231.

Messner DJ, Catterall WA (1985) The sodium channel from rat brain. Separation and characterization of subunits. J Biol Chem 260:1059710604.

Moorman JR, Kirsch GE, VanDongen AMJ, Joho RH, Brown AM (1990) Fast and slow gating of sodium channels encoded by a single mRNA. Neuron 4:243-252.

Moss B, Elroy-Stein O, Mizukami T, Alexander WA, Fuerst TR (1990) New mammalian expression vectors. Nature 348:91-92.

Negishi M, Glick MC (1986) Perturbation of glycoprotein processing affects the neurotoxin-responsive $\mathrm{Na}^{+}$channels in neuroblastoma cells. Carbohydr Res 149:185-198.

Noda M, Ikeda T, Kayano T, Suzuki H, Takeshima H, Kurasaki M, Takehashi H, Numa S (1986a) Existence of distinct sodium channel messenger RNAs in rat brain. Nature 320:188-192.

Noda M, Ikeda T, Suzuki H, Takeshima H, Takehashi H, Kuno M, Numa $S$ (1986b) Expression of functional sodium channels from cloned cDNA. Nature 322:826-828.

Noda M, Suzuki H, Numa S, Stuhmer W (1989) A single point mutation confers tetrodotoxin and saxitoxin insensitivity on the sodium channel II. FEBS Lett 259:213-216.

Perez-Reyes E, Kim HS, Lacerda AE, Horne W, Wei X, Rampe D, Campbell KP, Brown AM, Birnbaumer L (1989) Induction of calcium currents by the expression of the $\alpha_{1}$-subunit of the dihydropyridine receptor from skeletal muscle. Nature 340:233-236.

Roberts R; Barchi RL (1987) The voltage-sensitive sodium channel from rabbit skeletal muscle: chemical characterization of subunits. J Biol Chem 262:2298-2303.

Rogart RB, Cribbs LL, Muglia LK, Kephart DD, Kaiser MW (1989) Molecular cloning of a putative tetrodotoxin-resistant rat heart $\mathrm{Na}^{+}$ channel isoform. Proc Natl Acad Sci USA 86:8170-8174.

Sah P, Gibb AJ, Gage PW (1988) The sodium current underlying action potentials in guinea pig hippocampal CA1 neurons. J Gen Physiol 91:373-398.

Sanes JR, Rubenstein JLR, Nicolas J-F (1986) Use of a recombinant retrovirus to study post-implantation cell lineage in mouse embryo. EMBO J 5:3133-3142.

Scheuer T, Auld VJ, Boyd S, Offord J, Duun R, Catterall WA (1990) 
Functional properties of rat brain sodium channels in a somatic cell line. Science 247:854-858.

Scheuer T, West JTW, Maechler L, Catterall WA (1991) Efficient expression of rat brain sodium channel type IIA $\alpha$ subunits in Chinese hamster ovary cells. Biophys J 59:262a.

Schmidt JW, Catterall WA (1986) Biosynthesis and processing of the $\alpha$ subunit of the voltage-sensitive sodium channel in rat brain neurons. Cell 46:437-445.

Schubert B, VanDongen AMJ, Kirsch GE, Brown AM (1989) $\beta$-Adrenergic inhibition of cardiac sodium channels by dual $G$-protein pathways. Science 245:516-519.

Sills MN, Xu YC, Baracchini E, Goodman RH, Cooperman SS, Mandel $\mathrm{G}$, Chien $\mathrm{KR}$ (1989) Expression of diverse $\mathrm{Na}^{+}$channel messenger RNAs in rat myocardium-cvidence for a cardiac-specific $\mathrm{Na}^{+}$channel. J Clin Invest 84:331-336.

Stuhmer W, Conti F, Suzuki H, Wang X, Noda M, Yahagi N, Kubo $H$, Numa $S$ (1989) Structural parts involved in activation and inactivation of the sodium channel. Nature 339:597-603.

Sutton F, Davidson N, Lester HA (1988) Tetrodotoxin-sensitive voltage-dependent $\mathrm{Na}^{+}$currents recorded from Xenopus oocytes injected with mammalian cardiac muscle RNA. Mol Brain Res 3:187-192.

Thornhill WB, Levinson SR (1987) Biosynthesis of electroplax sodium channels in Electrophorus electrocytes and Xenopus oocytes. Biochemistry $26: 4381-4388$.

Trimmer JS, Cooperman SS, Tomiko SA, Zhou J, Crean SM, Boyle
MB, Kallen RG, Sheng Z, Barchi RL, Sigworth FJ, Goodman RH, Agnew WS, Mandel G (1989) Primary structure and functional expression of a mammalian skeletal muscle sodium channel. Neuron 3:33-49.

Ukomadu C, Zhou J, Sigworth FJ, Agnew WS (1991) Functional expression of rat skeletal muscle $\mu \mathrm{l}$ sodium channels in a mammalian cell line. Biophys J 59:69a.

Ulbricht W, Wagner H-H, Schmidtmayer J (1986) Kinetics of TTXSTX block of sodium channels. Ann NY Acad Sci 479:68-83.

Vassilev PM, Scheuer T, Catterall WA (1988) Identification of an intracellular peptide segment involved in sodium channel inactivation. Science 241:1658-1661.

Waechter CJ, Schmidt JW, Catterall WA (1983) Glycosylation is required for maintainance of functional sodium channels in neuroblastoma cells. J Biol Chem 258:5117-5123.

White MM, Chen L, Kleinfield R, Kallen RG, Barchi RL (1991) SkM2, a $\mathrm{Na}$ ' channel cDNA clone from denervated skeletal muscle, encodes a TTX-insensitive $\mathrm{Na}^{+}$channel. Mol Pharmacol 39:604-608.

Yamamoto D, Yeh JZ, Narahashi T (1984) Voltage-dependent calcium block of normal and tetramethrin-modified single sodium channels. Biophys J 45:337-344.

Yang X-C, Karschin A, Labarca C, Elroy-Stein O, Moss B, Davidson $\mathrm{N}$, Lester HA (1991) Expression of ion channels and receptors in Xenopus oocytes using vaccinia virus. FASEB J 5:2209-2216. 